\section{AL-AZHAR}

Assiut Dental Journal
The Official Publication of The

Faculty of Dental medicine.

Al-Azhar Assiut Uniuersity.

Egypt

\title{
The Effect of Miswak versus Chlorhexidin Gel on Subgingival Microbiota (Clinical and Microbiological Study)
}

\author{
Doaa Ahmed Fathy Abd ${ }^{* 1}$, Khalid Seddik Hassan ${ }^{1}$, Mohamad Fouad Edrees ${ }^{1}$
}

Codex : 07/1901

Aadj@azhar.edu.eg

\section{KEYWORDS}

Antimicrobial, CHX., Chronic

Miswak, periodontitis, P.gingivalis,

1. 1Department of Oral Medicine, Periodontology, Oral Diagnosis, and Dental Radiology, Faculty of Dentistry , Al-Azhar University ,Assiut.

* Corresponding author e-mail : Doaaabdo.19@azhar.edu.eg

\begin{abstract}
Aim: This study evaluates the clinical and microbiological effect of miswak and chlorhexidine gel on subgingival microbiota. Subjects and Methods: A full mouth randomized controlled clinical trial that carried out on 45 patients of both sex with mild to moderate chronic periodontitis. Selected patients were classified randomly into three equal group. After receiving the basic periodontal therapy group I used miswak 5 time a day (in accordance with the religious tradition), group II used CHX gel with tooth brush twice time daily, group III used tooth brush alone twice time daily. They evaluated clinicaly by Gingival Index, Plaque Index, Propping Depth and Attachment level at base line, after scalling and root blanning, one week, one month and finally after three month of using of each method, and microbiologically for detection and assessment of P.gingivalis at base line, after scalling and root blanning, one week, one month and finally after three month. Resultes: The present study exhibit that miswak more effective than tooth brush, as antimicrobial aginist $\mathrm{p}$. gingivalis. There was no significant difference in the efficacy of miswak and CHX. Conclusion: Miswak more effective than tooth brush, as antimicrobial agonist.
\end{abstract}

\section{INTRODUCTION}

Periodontitis is a biofilm-induced chronic inflammatory disease that leads to the destruction of the periodontium. Dental plaque is required but not sufficient to induce periodontitis, because the host inflammatory response to this microbial challenge that ultimately can cause destruction of the periodontium1. Diagnosis of chronic periodontitis is mostly based on an array of clinical measurements that include clinical attachment level, bleeding on probing, probing depth and radiographic findings2. plaque develops and matures over a period of several weeks, initially developing supragingivally with mainly aerobic bacteria. Over time, the flora changes from predominantly gram-positive to gram-negative, from facultative aerobes to strictly anaerobic species, with more motile forms present. 
Mature subgingival biofilm takes up to 12 weeks to develop3. Porphyromonas gingivalis is a Gramnegative, immobile ,asaccharolytic, obligate anaerobic rod, found mainly immersed in the subgingival microflora4. Because of its ability to produce a large quantity of virulence factors, it is considered to be a major pathogen in the onset and development of chronic periodontitis5. Personal oral hygiene maintenance is the key factor in the long-term preservation of periodontal health. Since chronic form of periodontitis is plaque oriented There are different methods available for maintenance of oral health; mainly mechanical and chemical. Tooth brush and dentifrices are widly used for cleaning the teeth ,miswak has been used since ancient histor6. The conventional meaning of miswak is stick used on tooth and gums to clean them1. The root of Salvadora persica contains a steam-distillable oil composed of $90 \%$ Benzyl iso thiocyanate (BIT) and $10 \%$ benzyl nitrate. It has been proposed that; these chewing sticks have anti-plaque effects and postulated that they may also affect the pathogenesis of periodontal disease by reducing the virulence of periodontopathic bacteria7. as an antimicrobrial agent, chlorhexidine is 2 effective in vitro against both Gram-positive and Gram-negative bacteria including aerobes and anaerobes and yeasts and fungi8, also chlorhexidine can reduce the adherence of Porphyromonas gingivalis to epithelial cells9. In this respect, it is very important to evaluate the efficacy of variable methods on the subgingival micropiota and oral haigen improving.

\section{SUBJECTS AND METHODS}

This study was designed as a full mouth randomized controlled clinical trial that carried out on 45 patients of both sex ( 24 females and 21 males ranged in age from 28-45 years) with mild to moderate chronic periodontitis. All patients were free from any systemic diseases, all patients showing probing pocket depth not more than
$5 \mathrm{~mm}$ and clinical attachment level (CAL) less than $5 \mathrm{~mm}$. Selected patients were classified randomly into three equal group after recciving the basic periodontal therapy group I used miswak 5 time aday [in accordance with the religious tradition], group II used CHX gel with tooth brush twice time daily, group III used tooth brush alone twice time daily.

\section{Periodontal treatment:}

For each group, thorough scaling and root planning was performed using hand instruments1 Gracey curettes and scalers and ultrasonic device2.

\section{After scaling and root planing:}

Group I instructed to use fresh miswak, its colour is light brown, $15 \mathrm{~cm}$ length, and $0.7-1 \mathrm{~cm}$ diameter, the Functional end of the miswak is striped off followed by chewing to give brush like appearance that helps in cleaning the teeth and massaging the gums. Time of brushing $5 \min 10$.

Group II instructed to use CHX gel (D.G care tooth paste) 3 twice daily and brush with Bass method technique, for 2 min. group III instructed to use tooth brush with soft bristles by using bass method for $2 \mathrm{~min}$ as recommended by ADA11. Periodontal Evaluation: the periodontal conditions were evaluated for all patients at baseline, after scalling and root planing, one week, one month, 3 months after treatment using plaque Index (PI), gingival Index (GI), probing Pocket Depth (PPD), clinical Attachment Level (CAL) Probing depth and attachment Level measured using Wiliams graduated periodontal probe.

\section{Microbiological evaluation:}

Gingival Crevicular Fluid (GCF) samples were obtained from the site which showed the highest probing depth (range 4-5 $\mathrm{mm}$ ). selected teeth for isolated with cotton roll, and supragingival plaque was removed without touching the marginal 
gingiva. Samples of GCF were obtained before probing into the site by using sterilized paper point 4 . The collected GCF was immediately transferred into an Eppendorf tube containing phosphate buffer saline and transported to the laboratory for DNA extraction. Samples were screened and quantitatively analyzed for $P$ gingivalis by quantitative Real time PCR using SYBR Green technology. GCF samples were collected at base line, after scalling and root planing, one week, one month, and 3 months after treatment using.

1. Hu-Friedy, Chicago, Finland

\section{EMS Mini Piezon Switzerland}

3. Al Esraa Pharm. Optima

\section{4. $\quad$ Paper point size\# 30}

\section{Statistical analysis:}

The data was collected, tabulated, computed and statistically analyzed. Data were explored for normality using Kolmogorov-smirnov and Shapiro-wilk tests, and showed parametric (normal) distribution for all parameters. One-way ANOVA followed by Tukey post-hoc test was used to compare between more than two groups in nonrelated samples. Repeated measure ANOVA was used compare between more than two groups in related samples. Paired sample t-test was used to compare between two groups in related samples. The significance level was set at $P \leq 0.05$. Statistical analysis was performed with IBM ${ }^{\circledR} \quad$ SPSS ${ }^{\circledR}$ Statistics Version 20 for Windows.

\section{RESULTS}

A statistically significant difference between means of plaque index in all groups at the different intervals when compared to the baseline. A statistical significant difference between group III and each of group I, group II, and there is no significant defrance between group I and group II at 3 months interval. Table (1)

A statistically significant difference between means of gingival index in the three groups at the different intervals when compared to the baseline. a statistical significant difference in group III when compared with group I and group II, no statistically significant difference was found between group I and group II Table(1). There was a statistically significant difference between means of probing pocket debth measurment in each group at the different intervals when compared to the baseline. a statistical significant difference in group III when compared with group II and group I at 3 months, no statistical significant difference between group I and group II Table (1).

A statistically significant difference between attachment level Measurements in each group at the different intervals when compared to the baseline, a statistical significant difference in group III when compared with group II and group I and no statistical significant difference between group I and group II Table (1).

A statistically significant difference reduction was found between bacterial copy number in all groups at the different intervals compared to base line a statistical significant difference in group III when compared with group II and group I and no statistical significant difference between group I and group II Table (1).

There was non-significant positive relationship between Microbiological results and plaque index, gingival index, and pocket depth but there was a significant positive relationship between Microbiological results and Attachment level Table (2). 
Table (1) The p.vale of antibacterial effect, plaque index, gingival index, pocket depth, and attachment level groups

\begin{tabular}{|c|c|c|c|c|c|}
\hline p.vale & Variables & & & & \\
\hline $\begin{array}{c}\text { Attatchment } \\
\text { Level }\end{array}$ & $\begin{array}{l}\text { Pocket } \\
\text { depth }\end{array}$ & $\begin{array}{l}\text { Gingival } \\
\text { index }\end{array}$ & $\begin{array}{l}\text { Plaque } \\
\text { index }\end{array}$ & $\begin{array}{c}\text { Antibacterial } \\
\text { Effect }\end{array}$ & \\
\hline Base & $0.862 \mathrm{~ns}$ & $0.076 \mathrm{~ns}$ & $0.776 \mathrm{~ns}$ & $0.632 \mathrm{~ns}$ & $0.183 \mathrm{~ns}$ \\
\hline After scalling & $0.920 \mathrm{~ns}$ & $0.076 \mathrm{~ns}$ & $* 0.019$ & $* 0.001$ & $0.192 \mathrm{~ns}$ \\
\hline$*>0.001$ & $* 0.018$ & $* 0.011$ & $*_{>}>0.001$ & $* 0.010$ & After 1 week \\
\hline After 1 month & $*>0.001$ & $* 0.010$ & $* 0.009$ & $*>0.001$ & $* 0.003$ \\
\hline$*>0.001$ & $*>0.001$ & $*>0.001$ & $*>0.001$ & $* 0.001$ & After 3 Months \\
\hline
\end{tabular}

Table (2) Coreltion between Microbiological result with plaque index, gingival index, pocket depth

\begin{tabular}{|c|c|c|c|c|}
\hline $\begin{array}{c}\text { Microbiological } \\
\text { result with }\end{array}$ & Variables & \multicolumn{2}{|l|}{} & \multirow{2}{*}{} \\
\cline { 1 - 4 } $\begin{array}{c}\text { Attachment } \\
\text { Level }\end{array}$ & $\begin{array}{c}\text { Gingival } \\
\text { index }\end{array}$ & $\begin{array}{c}\text { Pocket } \\
\text { depth }\end{array}$ & $\begin{array}{c}\text { Plaque } \\
\text { index }\end{array}$ & \\
\hline 0.202 & 0.106 & 0.150 & 0.219 & $\begin{array}{c}\text { Correlation } \\
\text { Coefficient }\end{array}$ \\
\hline sign. $>0.05$ & 0.056 & 0.319 & 0.157 & 0.092 \\
\hline
\end{tabular}

\section{DISCUSSION}

This study was degsined to evaluate the clinical and microbiological effect of miswak and chlorhexidine gel on subgingival microbiota. The time period for the present investigation was kept at 3 months. We depend on Real-time PCR to realize the antimicrobial effect of miswak and CHX as Real-PCR offers a sensitive, efficient, and reliable approach to quantitation. Using the Taq Man system able us to determine both the amount of Porphyromonas gingivalis and the total number of bacterial cells present in GCF samples as reported by Sharon R et al (2000)12.

The microbiological result of present study showed a statistically significant difference between tooth brush user group and Miswak user group, and no statistically significant difference was found between Miswak user group and CHX user. These results in accordance to the findings by Alali et al (2004)13, they reported that Salvadora persica (Miswak) stems exhibits potent antibacterial activity against both Gram-positive and Gram-negative bacteria. These results are in consistent with Almas et al (1995)14, and Sofrata H et al (2011)15 they revealed that miswak action is a concentration dependent, and showed that the miswak exhibited stronger antibacterial activity against the Gramnegative bacteria especially $P$. gingivalis than the Gram-positive bacteria evaluated, as evidenced by the pronounced differences in inhibition zones associated. yet the inhibition zones were less pronounced that of Chlorhexidine solution at all concentrations.

These studies have linked Benzyl isothiocyanate, a component of Salvadora persica, to rapid and strong bactericidal effects gramnegative periodontal pathogens Aggregatibacter actinomycetemcomitans and Porphyromonas gingivalis compared to the antibacterial effects of mouthwash with chlorhexidine on Streptococcus mutans $16,17,18$. The clinical result of present study which include (the gingival index, plaque index, pocket depth and attachment level) show A statistically significant difference was found in Miswak and CHX user group over the tooth brush user group where $(p=0.001)$. 
These results are similar to the findings other studies among Ethiopian and Nigerian students and Saudi Arabian dental students, using Miswak and toothbrush was compared. These comparisons showed that Miswak was more effective than toothbrush in removing plaque19. Also, the present findings are in accordance to another doubleblinded, randomized trial in 72 cases of moderate gingivitis showed that there was a significant reduction in the plaque index $(\mathrm{PI})$, gingival index (GI), and bleeding index (BI) following the use of Salvadora persica extract chewing gum20. In addition Al-Otaibi et al (2003)21 concluded that the miswak is more effective than tooth brushing for reducing plaque and gingivitis when preceded by professional instruction regarding its correct application. the use of Miswak appeared to be more effective than tooth brushing for removing the plaque from the embrasures; thus, enhancing interproximal oral health this in accordance with the present findings as there is a significant reduction in plaque and gingival index in miswak user group more than found in tooth brush user group. A study by Malik et al (2014)22. proposed that miswak has comparable or at times greater chemical and mechanical capability in plaque removal. as showed in this study there a significant reduction in plaque index in miswak user group. .Kaur et al (2004)23. indicated that commercially available miswak chewing sticks, in addition to containing high amounts of calcium and chloride, may possibly release phosphate and thiocyanate into the saliva. These findings suggest that the commercially available miswak used as chewing sticks may have the potential to release substances into the saliva that could influence the state of oral health.

\section{CONCLUSIONS}

Miswak has been proven effective as an oral hygiene aid and must be introduced to general population based on a scientific rules. Suggested that miswak must play an important role in periodontal disease prevention.

\section{REFERENCES}

1. Holtfreter B, Demmer R.T, Papapanou P.N, et al. A comparison of periodontal status in the two regional, population-based studies of SHIP and INVEST J Clin Periodontol.2012; 39:1115-24

2. American Academy of Periodontology Task Force Report on the Update to the 1999 Classification of Periodontal Diseases and Conditions. J. Periodontol. 2015; 86: 835-38.

3. Darveau R.P. Periodontitis: apolymicrobial disruption of homeostasis Nat. Rev. Microbiol. 2010; 8:481-90.

4. Bostanci N, Belibasakis G. N. Porphyromonas gingivalis: an invasive and evasive opportunistic oral pathogen. FEMS Microbiol. Lett.2012; 333:1-9.

5. Kataoka S, Baba A, Suda Y, Takii R, et al. A novel, potent dual inhibitor of Arggingipains and Lys-gingipain as a promising agent for periodontal disease therapy. FASEB J.2014; 28: 3564-78.

6. Rose L.F, Brian L., Jenco M.R. Periodontal evaluation treatment planing and nonsurgical therapy. Periodontics Medicine surgery, 2004; 2(4): 235-27.

7. Baehni P.C, Giovannoli J.L. Patient profile and decisionmaking in periodontal practice. Periodontol 2000. 2004;36:27-34.

8. Hyson J M. History of The Toothbrush. J Hist Dent 2003; 80:51:73

9. Homer A, Manji F, Beighton D. Inhibition of protease activities of periodontopathic bacteria by extracts of plants used in Kenya as chewing sticks (miswak). Arch Oral Biol 1990; 35: 421-24.

10. Al-Bagieh N.H, Weinberg E.D. ylisothiocyanate: a possible agent for controlling dental caries. Microbios. 1988; 39:143-151.

11. Carranza F.A. Clinical periodontology: Saunders, 9th Edn: 2003; 651-4

12. Sharon R, Lyons A, Griffen L, et al. Quantitative RealTime PCR for $\mathrm{P}$.gingivals and total bacteria. $\mathrm{J}$ of clinc microbiology. 2000;23625.

13. Alali F, Hudaib M, Aburjai $\mathrm{T}$, et al. Analysis and Antimicrobial Activity of the Essential Oil from the Stem of the Jordanian Toothbrush Tree Salvadora persica. Pharmaceu. Biol.2004; 42: 577-80.

14. Almas $\mathrm{K}$ and $\mathrm{Al}$ - Lafi $\mathrm{T}$. The natural toothbrush. World Health Forum 1995; 16:206-10. 
15. Sofrata A, Santangelo E.M, Karlson A.K, et al. Benzyl isothioc -yanate, a major component from the roots of salvadora persica is highly active against gram- negative bacteria. PLoS One.2011; 6:e23045

16. Chelli-Chentouf N, C. Mullie C, A. Aoues A, et al. B. In vitro and in vivo antimicrobial activity of Algerian Hoggar Salvadora persica L. Extracts against microbial strains from children's oral cavity J Ethnopharmacol. 2012;144: 57-66.

17. Patel P.V, Shruthi S, Kumar S. Clinical effect of miswak as an adjunct to tooth brushing on gingivitis. J Indian Soc Periodontol. 2012;16: 84-8.

18. Darout I.A, Albandar J.M, Skaug N. Periodontal status of adult Sudanese habitual users of miswak chewing sticks or toothbrushes. Acta Odontol Scand. 2000; 58:25-30.

19. Norton, M.R. and Addy, M. Chewing sticks ver-sus toothbrushes in West Africa. A pilot study. Clinical Preventive Dentistry.1989;11: 11-13.
20. Amoian B, Moghadamnia A.A, Barzi S, et al. Salvadora persica extract chewing gum and gingival health: Improvement of gingival and probe-bleeding index. Complement Ther Clin Pract. 2010;16:121-123

21. Al-Otaibi M, Al-Harthy M, Söder B, et al. Comparative effect of chewing sticks and tooth brushing on plaque removal and gingival health. Oral Health Prev Dent. 2003;1:301-307.

22. Malik A.S, Shaukat M.S, Qureshi A.A, et al. Comparative effective -eness of chewing stick and toothbrush: A randomized clinical trial. NAm J Med Sci. 2014; 6: 333-7.

23. Kaur S, Abdul Jalil R, Akmar SL. The immediate term effect of chewing commercially available Meswak (Salvadora persica) on levels of Calcium, Chloride, Phosphate and Thiocyanate in whole saliva. Ann Dent Univ Malaya. 2004;11:51-9. 


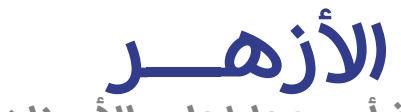 \\ مجلة أسيوط لطب الأسنان}

النشر الرسمي لكلية طب الأسنان جامعة الأزهر أسيوط السماية

AADJ, Vol. 2, No. 1, April (2019) — PP. 65

الملخص العربي

الغرض من الدراسة:

أجريت هذه الدراسـة لتقييم التأثير الاكلينيكي والميكروبيولوجيلا لالسـواك والكلورهيكسيدين جل على البكتيريا خت اللثوية.

الموضوعاث والأساليب:

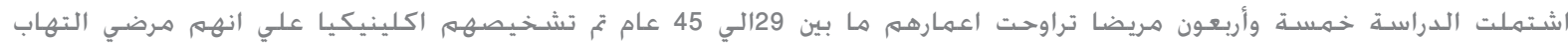

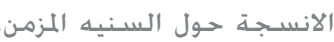

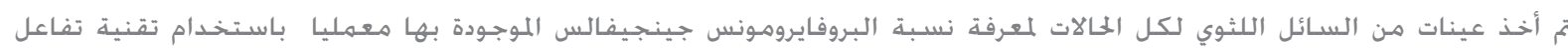

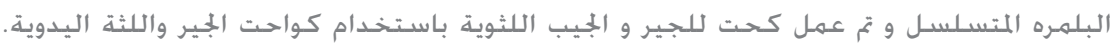

• تم تقسيم المرضى إلى ثلاث مسجهوعات.

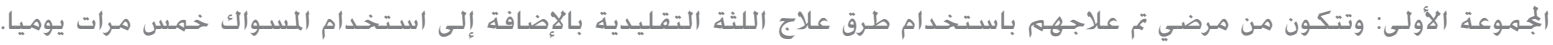

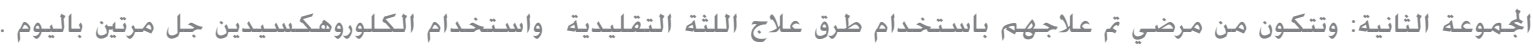

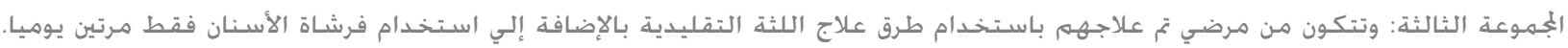

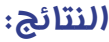
أظهرت نتائه هذه الدراسـة ما يلي: أولا: وجـود فروق إحـصائية في قياس طبقة البـلاك , دليل قياس إلتهاب اللثة, قياس الجيوب اللثوية , ومستوى التصاق اللثة بعد العـلاج في كل

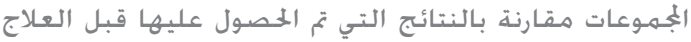

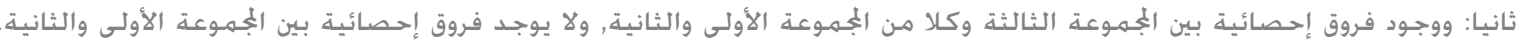
دليل قياس التغيير في عدد النسـخ البكتيرية أولاً: وجـود فروق إحـصائية في دليل قياس التغير في عدد النسـخ البكتيرية في كل الجُمـوعات حلال فترة الدراسـة مقارنة قبـل العـلاج.

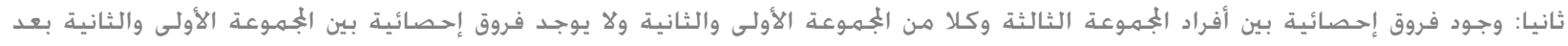
ثلاث اشهر من العلاج. 